Dicle Tıp Dergisi / Dicle Medical Journal (2017) 44 (4) : 325-332

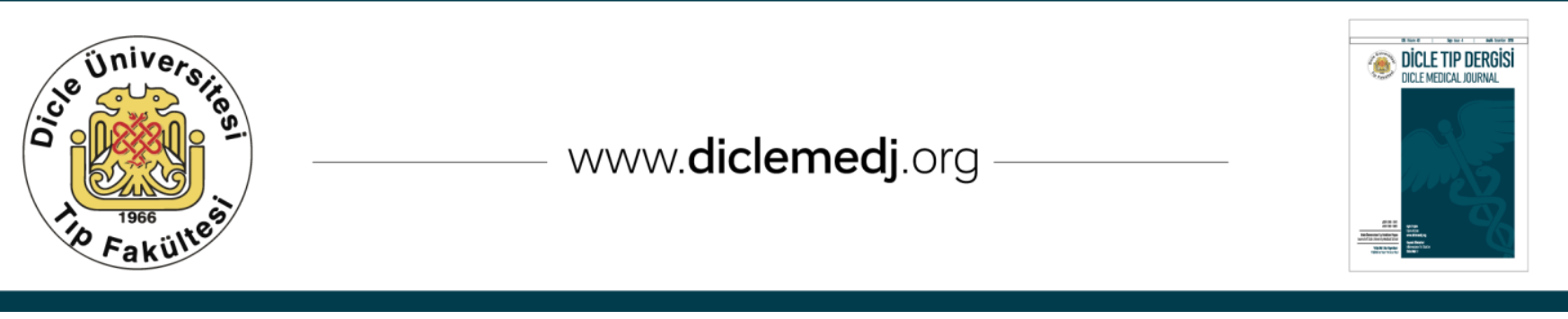

Özgün Araștırma / Original Article

\title{
İntraartiküler propolis ekstraktının erişkin sıçanlarda deneysel osteoartrit tedavisinde etkinliği
}

\author{
Gökçen Kerimoğlu1', Mehmet Emre Baki², Kübra Akbulut Çakıroğlu³ \\ 1 Karadeniz Teknik Üniversitesi Tıp Fakültesi Histoloji ve Embriyoloji Anabilim Dalı, Trabzon, Türkiye ORCID: 0000-0002-4349-7796 \\ 2 Karadeniz Teknik Üniversitesi Tıp Fakültesi Ortopedi ve Travmatoloji Anabilim Dall, Trabzon, Türkiye ORCID: 0000-0001-7002-6554 \\ 3 Karadeniz Teknik Üniversitesi Tip Fakültesi Biyokimya Anabilim Dall, Trabzon, Türkiye ORCID: 0000-0003-0227-5174
}

Geliş: 18.03.2017, Revizyon: 09.05.2017, Kabul Tarihi: 05.10.2017

\section{Özet}

Amaç: Eklem kıkırdağının kendini tamir edebilme yeteneği oldukça sınırlıdır. Dejeneratif osteoartrit (OA), eklemde özellikle eklem kıkırdağı ve subkondral kemikte ilerleyici dejenerasyonla karakterizedir. Bazı sitokinler, matriks metalloproteinazlarının (MMP) ve kondrosit kaynaklı katabolik maddelerin salınımını artırarak kıkırdak harabiyetini hızlandırırlar. Bal arıları tarafından üretilen propolis sitokinler ve MMP üzerinde etkiye sahiptir. Bu çalışma; intraartiküler propolis uygulanmasının deneysel osteoartrit üzerine etkilerini araştırmayı amaçlamaktadır.

Yöntemler: Çalışmada kullanılan 21 adet Spraque Dawley cinsi dişi sıçan sadece artrotomi yapılan (A), artrotomi ve intraartiküler propolis uygulanan (P) ve artrotomi ve intraartiküler serum fizyolojik uygulanan (SF) olmak üzere üç gruba ayrıldı. P grubuna artrotomi sonrası 3. haftadan itibaren toplam üç hafta, haftada bir kez olacak şekilde 0.5 $\mathrm{mg} / \mathrm{ml}$ konsantrasyondaki propolisten $0.1 \mathrm{ml}$ intraartiküler verildi. SF grubuna ise P grubuyla aynı zamanlarda serum fizyolojik verildi. 6 . hafta sonunda bütün sıçanlar servikal dislokasyon yoluyla sakrifiye edildi ve alınan diz eklemleri Safranin O-Fast Green ile boyanarak Mankin Skorlamasına göre histolojik olarak değerlendirildi.

Bulgular: Yapılan histolojik skorlamada gruplardaki ortalama skorlar;A grubunda 0.57; SF grubunda 10.1 ve P grubunda ise 5.57 puan olarak hesaplanmıştır. A grubunda; eklem yüzeyi kıkırdak yapısının, boyanmasının ve hücrelerinin genel olarak normal olduğu görüldü. SF grubunda, kıkırdak yüzeyinde yarıklar; hücrelerinde ve matriks boyanmasında ciddi bozukluk mevcut olduğu gözlendi. P grubunda ise boyanmada azalma ve hücrelerde gruplaşmalar görülse de eklem yüzeyi SF grubuna göre daha düzgündü.

Sonuç: İntraartikülerpropolisekstraktı uygulamasının deneysel OA oluşumunu azaltıcı etkisi olabilir.

Anahtar kelimeler: Propolis, osteoartrit, eklem kıkırdağı

DOI: $10.5798 /$ dicletip.362306

Yazışma Adresi / Correspondence: Gökçen Kerimoğlu, Histoloji ve Embriyoloji Ana Bilim Dalı Karadeniz Teknik Üniversitesi Tıp Fakültesi Trabzon, Türkiye e-mail: gokcen_kaplan@yahoo.com 


\title{
The effectiveness of intra-articular propolis extract on the treatment of experimental osteoarthritis in rats
}

\begin{abstract}
Objectives: The capacity for repair of articular cartilage is limited. Degenerative osteoarthritis (OA) is characterized by progressive degeneration in articular cartilage and subchondral bone. Some cytokines accelerate cartilage damage by increasing the release of catabolic substances originating from matrix metalloproteinases (MMP) and chondrocytes. The propolis produced by honeybees affects cytokines and MMPs. We investigated the effects of intra-articular propolis administration on experimental osteoarthritis.

Methods: 21 Sprague Dawley rats were divided into three groups, one group receiving arthrotomy alone (A), second group receiving arthrotomy and intra-articular propolis administration (P) and third group receiving arthrotomy and intra-articular saline solution (SF). Group $\mathrm{P}$ received $0.1 \mathrm{ml}$ intra-articular propolis at a concentration of $0.5 \mathrm{mg} / \mathrm{ml}$ once a week for three weeks, from the $3^{\text {rd }}$ week following arthrotomy. The SF group received saline solution at the same times as those in P group. All rats were sacrificed at the end of $6^{\text {th }}$ week. Tissue specimens were, stained with Safranin 0/Fast Green and subjected to histological evaluation based on the Mankin scoring system.

Results: The mean histological scores were 0.57 in A group, 10.1 in SF group and 5.57 in P group. Articular surface cartilage structure, staining and cells were generally normal in group A. In SF group, fissures were observed on the articular surface and severe impairment in cells and matrix staining. In P group, although a decrease was observed in staining and clustering, the articular surface was more regular than in SF group.

Conclusion: The application of intra-articular propolis may have a reduced effect on the development of experimental OA.
\end{abstract}

Keywords: Propolis, osteoarthritis, articular cartilage

\section{GİRIŞ}

Ağrısız hareketi sağlayan sinovyal eklemler; eklem kapsülü, ligamentler, menisküs, subkondral kemik, sinovyum ve hiyalin eklem kıkırdağı gibi pek çok farklı dokudan oluşur. Hepsinde yük taşıyan yüzey, eklem kıkırdağı ile örtülüdür. Eklem kıkırdağı, herhangi bir prostetik eklem yüzeyinden daha az sürtünmeyle ağrısız harekete müsaade eder. Yine üzerine gelen yükü dağıtarak subkondral kemik üzerine olan yansımayı da minimize eder ${ }^{1}$. Bu kadar üstün özelliklere sahip olan kıkırdak dokusunun kendi kendini tamir edebilme kapasitesi ise sinırlıdır ve yaş ilerledikçe de azalır.

Eklemde herhangi bir nedenle başlayan harabiyetin özellikle eklem kıkırdağı ve subkondral kemikte progresif hal alması; eklemde ağrı ve hareket kısıtlılığıyla karakterize dejeneratif osteoartrit (OA) ile sonuçlanır ${ }^{1-3}$. Osteoartrit patofizyolojisindeki mekanizmalardan birçoğu halen tam olarak bilinmese de süreç; kıkırdak matriks hasarı ya da değişimi, bu doku hasarına kondrosit cevabı ve kondrosit cevabinda azalma ile progresif doku kaybı olarak ilerler ${ }^{1,4}$. Bu süreçte özellikle interlökinler (IL) ve tümör nekroz faktörü alfa (TNF $\alpha$ ) gibi sitokinlerin önemli rolü vardır. Bu sitokinler matriks metalloproteinazları (MMP) ve katabolik enzimlerin kondrositlerden salınımını arttırarak normal eklem kıkırdağı döngüsündeki katabolik süreci arttırır ve dejenerasyonu da hızlandırırlar. Bunun yanı sıra özellikle IL'ler MMP inhibitörlerini de azaltarak normal eklem kıkırdağı döngüsündeki anaboliksüreci de yavaşlatırlar ${ }^{5-8}$.

Propolis bal arları tarafından bitki ve ağaçlardan toplanan kuvvetli yapışkan bir reçinedir. İçeriğinde aminoasitler, fenolik asitler, fenolik asit esterleri, flavonoidler, sinamik asit, terpenler ve kafeik asit ihtiva eder 9,10. Propolisin inflamatuvar sitokinler (özellikle 
IL1, IL6), MMP'ları, MMP inhibitörleri, prostoglandin (PG) E2 ve nitrik oksit (NO) ve TNF $\alpha$ üzerine olan etkilerini araştıran birçok deneysel çalışma mevcuttur 7,10-13.

$\mathrm{Bu}$ çalışmada propolisin inflamatuvar sitokinler üzerine olan etkileri düşünülerek, deneysel olarak oluşturulan OA modelinde intraartiküler propolis uygulamasının OA'in progresif seyrini yavaşlatması amaçlanmıştır.

\section{YÖNTEMLER}

Çalışmamız, etik kuruldan onayı alındıktan sonra (2015/36) cerrahi araştırma laboratuvarında yürütüldü. Ortalama ağırlıkları 275 gr (250-300) olan 20 haftalık, 21 adet Spraque Dawley cinsi dişi sıçan kullanıldı. Sıçanlar oda sıcaklığı $20-24^{\circ} \mathrm{C}$, aydınlık-karanlık döngüsü 14-10 saat olacak şekilde ayrı ayrı kafeslere yerleştirildi. Deney süresince standart sıçan yemi ve su kullanıldı. Bir haftalık takibin ardından sıçanlar rastgele üç gruba ayrıldı (A:artrotomi, SF: serum fizyolojik, P:propolis).

Cerrahi İşlem

Anestezi ve analjezi amacıyla $10 \mathrm{mg} / \mathrm{kg}$ xylazin hidroklorür (Rompun: Bayer, Leverkusen, Almanya) ve $50 \mathrm{mg} / \mathrm{kg}$ ketaminhidroklorür (Ketalar: Pfizer, İstanbul, Türkiye) intraperitonial olarak kullanıld. Gerekli olan durumlarda ilave ketamin uygulaması ile anestezi süresi uzatıldı. Sağ dizlere medial parapetaller kesi ile artrotomi yapıldı ve patella laterale kaydırıldı. Medial kollateral bağ kesildi. Medial menisküs çıkartıldı ${ }^{14,15}$. Sadece A grubunda cerrahi işlem artrotomi aşamasından sonra sonlandırıldı. Tüm sıçanlarda cerrahi işlem sonunda yumuşak doku ve cilt suture edilerek insizyon kapatıldı. İşlemler sonrasında bütün sıçanlar ayrı ayrı kafeslerine geri koyuldu ve harekete izin verildi. 6. hafta sonunda bütün sıçanlar servikal dislokasyon yoluyla sakrifiye edildi.

Propolisin Hazırlanışı

Türkiye'nin çeşitli yörelerinden toplanan propolis örnekleri toz haline getirilip karıştırıldı. Bunun 100 gr'ı 1000ml saf su ile çözüldü ve sürekli çalkalanarak 24 saat inkübasyona birakıldı. 24 saatin sonunda çalkalayıcı inkübatörden çıkartılan ekstrakt süzgeç kağıdında süzüldü ve ardından 0.22 $\mu$ m'lik steril filtrelerden geçirilerek kullanıma hazır hale getirildi. $\mathrm{Bu}$ şekilde hazırlanan 100 $\mathrm{mg} / \mathrm{ml}$ 'lik konsantrasyondaki stok propolis ekstraktından seyreltme yoluyla istenilen konsantrasyonlarda çalışma çözeltisi hazırlandi.

Eklem İçi Uygulama

$0.5 \mathrm{mg} / \mathrm{ml}$ konsantrasyonda olacak şekilde hazırlanan propolis çözeltisinin $0.1 \mathrm{ml}$ 'si cerrahi girişim sonrası 3. haftadan itibaren haftada bir kez olacak şekilde 3 kez P grubundaki sıçanların sağ dizlerine intraartiküler olarak enjekte edildi. SF grubuna ise aynı işlem $0.1 \mathrm{ml}$ serum fizyolojik uygulanarak yapıldı.

Histolojik Değerlendirme

Diz eklemi, femur distalinden ve tibia proksimalinden $1 \mathrm{~cm}$ 'lik kısımları içerecek şekilde alındı. Kas ve yumuşak dokuları uygun şekilde ayrildı ve \%10'luk formole koyuldu. Eklemler, 3 günlük fiksasyonun ardından $\% 10$ 'luk formik asitle hazırlanan dekalsifikasyon solüsyonunda bekletilerek dekalsifiye edildi. Tüm örnekler sagital planda, tam orta hattan kesildi ve medial kısımları alındı. Sonra örnekler dereceli alkol serilerinden geçirilerek dehidrate edildi, ksilen ile şeffaflaştırma işlemi uygulandı ve parafin bloklara gömüldü. Parafin bloklardan mikrotomla (Leica RM 2255, Leica Instruments, Nussloch, Germany) 5 mikrometrelik seri kesitler alındı. Kesitlerde tibiafemoral eklemin yük taşıyan medial bölgesinin görünür olmasına dikkat edildi. Bu kesitler Safranin 0Fast Green ile boyanarak sşık mikroskopunda (Olympus BX51) değerlendirildi ve fotoğrafları çekildi. Değerlendirme; eklem kıkırdağının yapısı, hücreleri, Fmatriksin safranin 0 ile boyanma miktarı ve tidemark'ın bütünlüğünün 
ayrı ayrı puanlanıp daha sonra toplam puanın eldesine dayanan ve sonuçta her eklem için hasarsızdan hasarlıya doğru 0-14 arasında bir toplam puana ulaşılan Mankin skorlaması ile yapıld 16 .

İstatistiksel Değerlendirme

Çalışmanın istatistiksel analizi IBM SPSS 22 ile yapılmıştır. Veriler Kruskall Wallis varyans analizi ile değerlendirilmiştir. Grupların ikili karşılaştırması ise Mann-Whitney $U$ testi ile yapılmıştır. Bu ikili karşılaştırmada Bonferroni düzeltmesi hesaplanarak anlamlılık düzeyi belirlenmiştir.

\section{BULGULAR}

Klinik Bulgular

Ameliyat sonrası ilk bir iki gün gözlemlenen topallama takip eden günlerde düzeldi. Enfeksiyon bulgusu gözlenmedi ve hiçbir siçan deney süresi boyunca ölmedi. Değerlendirilmek için alınan diz eklemlerinin hiçbirinde eklem hareketlerinde kısıtlılık gözlenmedi.

Histolojik Bulgular

Sıçanların sağ dizlerinin tibial eklem yüzleri Mankin Skoruna göre; eklemdeki hasarın eklem yüzeyindeki kıkırdak yapısını etkileme derecesi, kondrositlerin durumu, matriksin Safranin 0 ile boyanma miktarı ve tidemarkın bütünlüğü göz önüne alınarak mikroskopik olarak incelendi.

A grubunda; Safranin 0 ile boyanmanın normal olduğu, eklem yüzeyi ve kıkırdak yapının genel olarak düzgün, hücrelerin şekilleri, sayıları ve morfolojilerinin normal olduğu gözlendi. Eklemlerde herhangi bir doku kaybı yoktu. SF grubunda; Safranin O ile boyanmada azalma, eklem yüzeyinden alt tabakalara doğru uzanan yarıklar ve hücrelerde gruplaşmalar görüldü. $\mathrm{P}$ grubunda ise; Safranin 0 ile boyanmada hafif azalma ve hücrelerde gruplaşmalar olmakla beraber eklem yüzeyinin normale yakın olması dikkat çekiciydi (Resim 1).

Grupların ortalama histolojik skorları hesaplandığında; A grubunun 0.57, SF grubunun 10.1 ve $P$ grubunun ise 5.57 puan olduğu görülmüştür. Üç grubun toplam Mankin skorları karşılaştırıldığında istatistiksel olarak anlamlı fark vardı ( $\mathrm{p}<0.001)$ (Tablo 1). Bu fark bütün gruplar arasında toplam skorlar açısından ayrı ayrı mevcuttu $(\mathrm{p}<0.001)$. Yani eklem dejenerasyonundaki artış SF grubunda A grubuna göre anlamlı derecede fazla bulundu. $\mathrm{P}$ grubunda ise bu dejenerasyon artışı SF grubuna göre anlamlı derecede azalmıştı. Uygulanan propolis tedavisi eklemdeki dejenerasyonun progresyonunu anlamlı derecede azaltmıştı.

Tablo 1. Grupların Mankin skorları ve p değerleri

\begin{tabular}{llllllll}
\hline & \multicolumn{3}{c}{ Grup A } & \multicolumn{3}{c}{ Grup P } & \multicolumn{3}{c}{ Grup SF } \\
\cline { 2 - 8 } & n & Ort. \pm SD & N & Ort. \pm SD & n & Ort. \pm SD & P değeri \\
\hline Yapı & 7 & $0.14 \pm 0.37$ & 7 & $2.28 \pm 0.48$ & 7 & $4.28 \pm 0.48$ & $<\mathbf{0 . 0 0 1}$ \\
Hücreler & 7 & $0.28 \pm 0.75$ & 7 & $1.17 \pm 0.75$ & 7 & $2.42 \pm 0.53$ & $\mathbf{0 . 0 0 2}$ \\
Safranin0 Boyanma & 7 & $0.42 \pm 0.53$ & 7 & $1.71 \pm 0.75$ & 7 & $2.28 \pm 0.48$ & $\mathbf{0 . 0 0 1}$ \\
Tidemark Bütünlüğü & 7 & $0.00 \pm 0.00$ & 7 & $0.28 \pm 0.48$ & 7 & $0.71 \pm 0.48$ & $\mathbf{0 . 0 2 1}$ \\
Total Puan & 7 & $0.57 \pm 0.53$ & 7 & $5.57 \pm 0.78$ & 7 & $10.14 \pm 1.21$ & $<\mathbf{0 . 0 0 1}$
\end{tabular}

Ort. \pm SD: Ortalama \pm Standart sapma

$(\mathrm{p}<0.05$ anlamlı) 

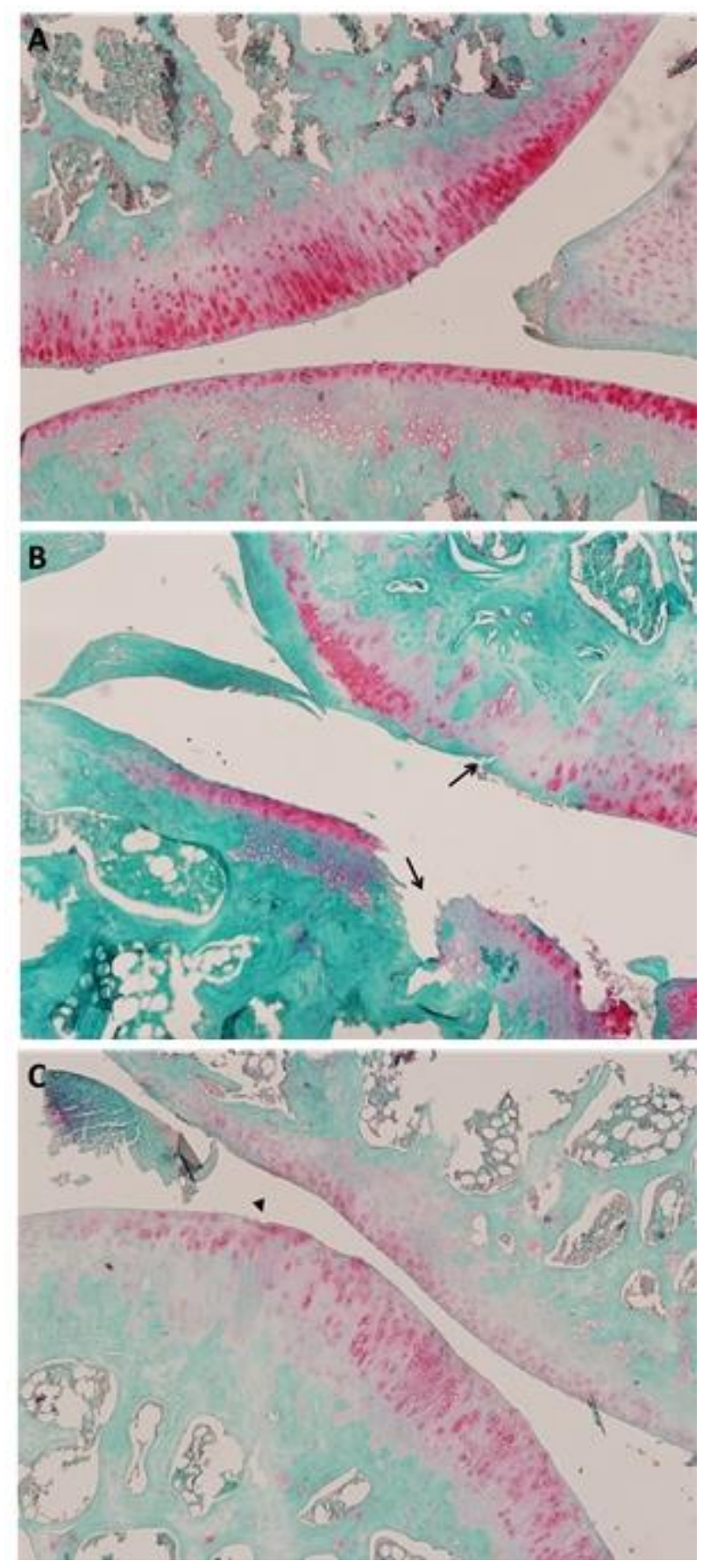

Resim 1. A grubunda (A) eklem yüzeyi, hücrelerin normal görünümde olduğu ve kıkırdak boyanmasının iyi olduğu görülüyor. SF grubunda (B) alt tabakalara doğru yarıklar (ok) ve boyanmada belirgin azalma dikkati çekiyor. P grubunda (C) ise yüzeysel düzensizliklerin (ok başı) ve kıkırdak boyanmasındaki azalmanın hafif olduğu görülmekte (Safranin O-Fast Green X100)

\section{TARTIȘMA}

Osteoartrit; ilerleyici kıkırdak erozyonu ve sinovyal inflamasyon ile karakterize en sik görülen artrit șeklidir ${ }^{17-19}$. Erken aşamalarında, eklemi olușturan tüm dokularda gözlemlenen değișen derecelerdeki inflamasyon temel patolojik değişikliktir ${ }^{19}$. Kıkırdak erozyonu ile sinovyal inflamasyon arasında açık bir ilişki olduğu gösterilmiştir ${ }^{18}$.

Osteoartritte gözlemlenen metabolizma bozukluğu inflamatuvar ve antiinflamatuvar sitokinler arasındaki sitokin iletişim ağının bozulmasından kaynaklanmaktadır ${ }^{19}$. OA'li eklemlerde IL1 $\beta$, TNF $\alpha$, IL6, IL15, IL17, IL18, IL21 gibi inflamatuvar sitokinlerin salınımının arttığı ve bunlarında patogenezde önemli rol oynadığ 1 bilinmektedir ${ }^{5-8,17,18,20}$. Bunlar arasindan IL1 $\beta$, TNF $\alpha$ ve IL6 patofizyolojideki en önemli sitokinler olarak gözükmektedir. $\mathrm{Bu}$ sitokinler oluşturdukları etkilerden dolayı eklem kıkırdağında destrüktif hasara neden olurlar. Bu etki sadece kondrositlerde yaşlanma ve apoptozis ile sinırlı olmayıp; yanı sıra proteoglikan, agregan ve tip II kollajen gibi ekstrasellüler matriks komponentlerinde azalma ile de meydana gelir5-8,19,21. İlave olarak bazı sitokinler özellikle MMP'ları (MMP1, MMP3 ve MMP13) gibi birçok proteolitik enzimin sentezini ve salınımını da arttırır. Yine TNF $\alpha$, IL1, IL17 ve IL18 gibi sitokinler de aynı zamanda MMP inhibitörlerini de azaltırlar5-8,21. İnflamatuvar sitokinlerin kondrositler, sinoviyal hücreler, eklem ve eklem çevresi dokular üzerine olan etkilerinden başka immun sistem hücrelerini de etkileyip inflamasyon sahasına migrasyonlarını sağlayıcı özellikleri vardır. Bütün bu hücreler inflamatuvar PGE2, siklooksijenaz (COX) 2, fosfolipaz A2, NO ve serbest radikallerin aşırı miktarda üretilmesini sağlar ${ }^{19}$. Böylece eklemdeki tüm dokularda $\mathrm{OA}$ patofizyolojisini oluşturan anabolik süreçte yavaşlama, katabolik süreç ile inflamatuvar cevapta ise artış meydana gelir5,18,19. Bu durumda artık eklem kıkırdağında progresif fonksiyonel ve yapısal bir kayıp söz konusudur. 
$\mathrm{Bu}$ nedenle günümüzde $\mathrm{OA}$ 'in progresif seyrini durdurmaya yönelik arayışlar; çalışmaları, patofizyolojide oldukça önemli rol oynadığı düşünülen bu sitokinler ve MMP'lar üzerine odaklamaktadır.

Ma ve ark. adalimumab ile yaptıkları TNF $\alpha$ blokajını deneysel OA modelinde OA'in progresyonunu önlemek için kullandılar. Mankin skorlarını ve MMP 13 seviyelerini tedavi grubunda daha düşük buldular. Yine subkondral trabeküler mikro yapıdaki harabiyet ve ekstrasellüler matriks yıkılması da tedavi grubunda azalmıştı. Çalışma sonucunda yazarlar deneysel $\mathrm{OA}$ modelinde $\mathrm{TNF} \alpha$ blokajının OA'in progresyonunu azalttığını vurguladılar6.

Kandaki sitokin seviyelerinin değerlendirildiği bir çalışmada propolis içeriğindeki pinocembrinin (PB) TNF $\alpha$ 'nın yanı sıra, IL $1 \beta$ ve IL 6 seviyelerini de düşürdüğü vurgulanmıştır ${ }^{12}$. PB'nin in vitro bir çalışmada kondrositlerden MMP salınımını da (özellikle MMP1, MMP3 ve MMP13) inhibe ettiği belirtilmiştir7. MMP ve ilişkili enzimler ekstrasellüler matriks fonksiyonu ve döngüsünü kontrol ederler. OA gibi birçok kas iskelet sistemi hastalığında bu döngü MMP'lar lehine bozulmuştur ${ }^{8}$.

IL1 $\beta$, uyarılabilir nitrik oksit sentaz ve COX 2 seviyelerini arttırır. Böylece NO, ROS ve araşidonik asit metabolitleri artar. Özellikle NO kondrositlerden MMP'ın salınımını arttırır ve proteoglikan sentezini azaltır22-24. Yapılan çalışmalara göre; propolis içeriğindeki kafeik asit fenil ester (CAPE), insan kıkırdak doku kültürlerinde ve kondrositlerde IL1 $\beta$ seviyelerini azaltır ve dolayısıyla MMP'ların OA patofizyolojisindeki etkilerini de önlemiş olur22,25. Aynı zamanda CAPE inflamatuvar hastalıklarda anahtar rol oynayan $\mathrm{T}$ hücre aktivasyonunu uyaran reseptörler üzerinde potent inhibitördür. CAPE, uyarılmış $\mathrm{T}$ hücrelerinde IL-2 gen transkripsiyonunu ve IL2 sentezini de spesifik olarak inhibe eder ${ }^{26}$.
Hu ve arkadaşları yaptıkları çalışma sonucunda propolisin etanolikekstratının (EEP) kuvvetli antiinflamatuvar etkiye sahip olduğunu ve bu etkinin PGE2 ve NO seviyelerinin azalmasından kaynaklanmış olabileceğini söylediler ${ }^{11}$. Park ve Kahng'da benzer şekilde adjuvan artritli sıçanlarda EEP'nin hem kronik hem de akut inflamasyonda güçlü antiinflamatuvar özelliğe sahip olduğunu gözlemledi. Bu etkinin EEP'nin PG üretimindeki inhibitör etkisinden kaynaklanmış olabileceğini düşündüler ${ }^{27}$. Zheng ve arkadaşları ise osteoartritli hastaların kondrositlerine, in vitro olarak propoliste bulunan doğal bir flavanoid olan chrysin uyguladılar. Ve kondrositler üzerinde antiinflamatuvar etkisinin olduğunu, OA tedavisinde kullanılabileceğini bildirdiler ${ }^{28}$.

Bal arılarının,bitkilerden elde ettiği reçineli bir madde olan propolis; sahip olduğu çok sayıda organik ve inorganik içerik sayesinde geleneksel tıbbın bir parçasıdır. Günümüzde yapılan çalışmalar ise sahip olduğu antiviral, antibakteriyel, antiinflamatuvar ve antioksidan etkilerin pek çok hastalık için tedavi edici olabildiğinigöstermiştir ${ }^{29,30}$.

Mevcut çalışmada intraartiküler propolis tedavisi uygulanan gruptan elde edilen histolojik sonuçlar SF grubuna göre anlamlı derecede iyi çıkmıştır. Yani deneysel olarak oluşturulan kıkırdak dejenerasyonu, propolis verilen grupta kontrol grubuna göre daha az gerçekleşmiştir.

Sonuç olarak intraartiküler propolis uygulamasının deneysel OA oluşumu üzerinde yavaşlatıcı etkisi olduğu gözlenmiştir. $\mathrm{Bu}$ etkinin, propolisin içeriğindeki CAPE ve PB gibi ürünlerin $\mathrm{OA}$ patofizyolojisinde oldukça önemli rol oynayan interleukinler, TNF $\alpha$ ve MMP'ları etkileyerek gerçekleşmiş olabileceği kanaatine varılmıştır. Sonuçların biyokimyasal veriler ile desteklenmemiş olması çalışmanın zayıf yönüdür. 
*Çalışma, 12-15 Mayıs 2016 tarihinde İstanbul'da düzenlenen TOTDER 6. Ortopedi ve Travmatoloji İstanbul Buluşması'nda sözlü bildiri olarak sunulmuştur.

Çıkar Çatışması Beyanı: Yazarlar çıkar çatışması olmadığını bildirmişlerdir.

Finansal Destek: Bu çalışma her hangi bir fon tarafından desteklenmemiştir.

Declaration of ConflictingInterests: The authors declare that they have no conflict of interest.

Financial Disclosure: No financial support was received.

\section{KAYNAKLAR}

1. Buckwalter JA, Mankin HJ, Grodzinsky AJ. Articular cartilage and osteoarthritis. Instr Course Lect. 2005;54:465-80.

2. Teeple E, Jay GD, Elsaid KA, Fleming BC. Animal models of osteoarthritis: Challenges of model selection and anaylsis. AAPS J. 2013;15:438-46.

3. Bove SE, Leamont KD, Brooker RM et al. Surgically induced osteoarthritis in the rat results in the development of both osteoarthritis-like joint pain and secondary hyperalgesia. Osteoarthritis Cartilage. 2006;14:1041-8.

4. Buckwalter JA, Mankin HJ. Articular cartilage. J Bone Joint Surg Am. 1997;79:612-32.

5. Lorenz H, Richter W. Osteoarthritis: Cellular and molecular changes in degenerating cartilage. Prog Histochem Cytochem. 2006;40:135-63.

6. Ma $\mathrm{CH}, \mathrm{Lv} \mathrm{Q}, \mathrm{Yu} \mathrm{YX}$ et al. Protective effects of tumor necrosis factor- $\alpha$ blockade by adalimumab on articular cartilage and subchondral bone in a rat model of osteoarthritis. Braz J Med Biol Res. 2015;48:863-70.

7. Zhang D, Huang B, Xiong C, Yue Z. Pinocembrin inhibits matrix metalloproteinase expression in chondrocytes. IUBMB Life. 2015;67:36-41.

8. Pasternak B, Aspenberg P. Metalloproteinases and their inhibitors-diagnostic and therapeutic opportunities in orthopedics. ActaOrthop. 2009;80:693-703.

9. Oner M, Kafadar I, Guney A et al. Effect of intraarticular propolis in an experimental septic arthritis model. J Pediatr Orthop B. 2011;20:8-13.
10. Khalil ML. Biological activity of bee propolis in health and disease. Asian Pac J Cancer Prev. 2006;7:22-31.

11. Hu F, Hepburn HR, Li Y, Chen M, Radloff SE, Daya S. Effects of ethanol and water extracts of propolis (bee glue) on acute inflammatory animal models. J Ethnopharmacol. 2005;100:276-283.

12. Soromou LW, Jiang L, WeiM et al. Protection of mice against lipopolysaccharide-induced endotoxic shock by pinocembrin is correlated with regulation of cytokine secretion. J Immunotoxicol. 2014;11:56-61.

13. Gao M, Zhu SY, Tan CB, Xu B, Zhang WC, Du GH. Pinocembrin protects the neurovascular unit by reducing inflammation and extracellular proteolysis in MCAO rats. J Asian Nat Prod Res. 2010;12:407-18.

14. Bendele AM. Animal model of osteoarthritis. J Musculoskelet Neuronal Interact. 2001;1:363-76.

15. Janusz MJ, Bendele AM, Brown KK, Taiwo YO, Hsieh L, Heitmeyer SA. Induction of osteoarthritis in the rat by surgical tear of the meniscus: Inhibition of joint damage by a matrixmetalloproteinase inhibitor. Osteoarthritis Cartilage. 2002;10:785-791.

16. Pearson RG, Kurien T, Shu KSS, Scammell BE. Histopathology grading systems for characterisation of human knee osteoarthritis-reproducibility, variability, reliability, correlation, andvalidty. Osteoarthritis Cartilage. 2011;19:324-31.

17. Fernandes JC, Martel-Pelletier J, Pelletier JP. The role of cytokines in osteoarthritis pathophysiology. Biorheology. 2002;39:237-46.

18. Kapoor M, Martel-Pelletier J, Lajeunesse D, Pelletier JP, Fahmi H. Role of proinflammatory cytokines in the pathophysiology of osteoarthritis. Nat Rev Rheumatol. 2011;7:33-42.

19. Wojdasiewicz P, Poniatowski LA, Szukiewicz D. The role of inflammatory and anti-inflammatory cytokines in the pathogenesis osteoarthritis. Mediators Inflamm. 2014;2014:561459.

20. Liu Y, Peng H, Meng Z, Wei M. Correlation of IL-17 level in synovia and severity of knee osteoarthritis. Med Sci Monit. 2015;21:1732-6.

21. Bramono DS, Richmond JC, Weitzel PP, Kaplan DL, Altman GH. Matrix metalloproteinases and their clinical applications in orthopaedics. Clin Orthop Relat Res. 2004;428:272-85.

22. Cardile V, Panico A, Gentile B, Borrelli F, Russo A. Effect of propolis on human cartilage and chondrocytes. Life Sci. 2003;73:1027-35. 
23. Cipolletta C, Jouzeau JY, Geqout-Pottie $P$ et al. Modulation of IL-1-induced cartilage injury by NO synthase inhibitors: a comparative study with rat chondrocytes and cartilage entities. Br J Pharmacol. 1998;124:1719-27.

24. Lyons-Giordano B, Pratta MA, Galbraith W, Davis GL, Arner EC. Interleukin-1 differentially modulates chondrocyte expression of cyclooxygenase- 2 and phospholipase A2. Exp Cell Res. 1993;206:58-62.

25. Armutcu F, Akyol S, Ustunsoy S, Turan FF. Therapeutic potential of caffeic acid phenethyl ester and its anti-inflammatory and immunomodulatory effects (Review). Exp Ther Med. 2015;9:1582-8.

26. Marquez N, Sancho R, Macho A, Calzado MA, Fiebich BL, Munoz E. Caffeic acid phenethyl ester inhibits T-cell activation by targeting both nuclear factor of activated
$\mathrm{T}$ cells and NF-kappa B transcription factors. J Pharmacol Exp Ther. 2004;308:993-1001.

27. Park EH, Kahng JH. Suppressive effects of propolis in rat adjuvant arthritis. Arch Pharm Res. 1999;22:554558.

28. Zheng W, Tao Z,Cai L, et al. Chrysin Attenuates IL-1ßInduced Expression of Inflammatory Mediators by Suppressing NF- $\mathrm{B}$ in Human Osteoarthritis Chondrocytes. Inflammation. 2017;40:1143-54.

29. Viuda-Martos M, Ruiz-Navajas Y, Fernández-López J, Pérez-Alvarez JA. Functional properties of honey, propolis, and royal jelly. J Food Sci. 2008;73:R117-24.

30. Khalil ML. Biological activity of bee propolis in health and disease. Asian Pac J Cancer Prev.2006;7:22-31. 